\title{
Identifikasi Koeksistensi Arsitektural pada Rumah Tradisional Walaka dan Bangunan DPRD di Kota Baubau
}

\author{
Muhammad Zakaria Umar ${ }^{1}$, La Ode Abdul Rachmad Sabdin Andisiri ${ }^{1}$ \\ 1Jurusan Arsitektur, Fakultas Teknik, Universitas Halu Oleo, Indonesia \\ muzakum.uho@gmail.com \\ doi.org/10.29080/ emara.v4i1.221
}

\begin{abstract}
Coexistence in architecture was considered as the process of cooperation between two or more different architectural styles and synergized each others. The Old Buton society consists of Kaomu, Walaka, Maradika, and Batua. The social stratification system in Buton society was reflected in its dwelling. In the architectural context, various attempts to rediscover the identity in each of his work were very pronounced, with varying results. The study was aimed to identified coexistence between Walaka's house and parliament building using a comparative causal approach. The results concluded that the coexistence between the Walaka's houses and parliament building could be found in the form of philosophical, meanings, symbols, function on the modified floor plan, view, and sections. The coexistence between the house of Walaka's with govermental position and parliament building could not be found between under the Walaka's house and the parliament building foundation, tangkebala sasambiri and overstek console at parliament building and the Walaka's box-shaped pabate and the overstek console from parliament building. The philosophical coexistence was also not founded between wide large and latticed windows at Walaka's house with ones at parliament building, the Walaka's bosu bosu and the overstek console without ornament at parliament building, as well as the Walaka's double-decker roof and the parliament's double-decker roof.
\end{abstract}

Keywords: coexistence, Walaka's house, parliament building

\begin{abstract}
Abstrak: Koeksistensi dalam arsitektur disebut sebagai proses kerjasama antar dua atau lebih gaya arsitektur yang berbeda dan saling bersinergi. Masyarakat Buton Lama terdiri dari kaum Kaomu, Walaka, Maradika, dan Batua. Sistem stratifikasi sosial dalam masyarakat Buton sendiri tercermin dalam huniannya. Dalam bidang arsitektur, terasa sekali adanya upaya untuk menemukan kembali jati diri dalam setiap karya dengan berbagai hasil upaya yang beragam. Penelitian ini ditujukan untuk mengidentifikasi koeksistensi arsitektur antara rumah kaum Walaka dengan bangunan DPRD. Penelitian ini merupakan penelitian kualitatif dengan pendekatan kausal komparatif terhadap rumah kaum Walaka dan bangunan DPRD. Dari hasil penelitian dapat disimpulkan bahwa koeksistensi rumah kaum Walaka dan bangunan DPRD terdapat pada aspek filosofi, makna, simbol, fungsi denah, tampak, serta potongan yang telah dimodifikasi. Koeksistensi antara rumah kaum Walaka yang mempunyai kedudukan dan bangunan DPRD tidak terdapat pada kolong rumah kaum Walaka dan pondasi bangunan DPRD, sasambiri tangkebala (rumah kaum Walaka) dan konsol overstek bangunan DPRD, pabate berbentuk kotak pada rumah kaum Walaka) dan konsol overstek bangunan DPRD. Koeksistensi dalam filosofi dan makna juga tidak terdapat antara bentuk jendela yang besar, luas, dan berteralis antara rumah kaum Walaka dan bangunan DPRD. Koeksistensi juga tidak terdapat antara bosubosu rumah kaum Walaka dan konsol overstek tanpa ornamen pada bangunan DPRD serta atap rumah bersusun antara rumah kaum Walaka dan bangunan DPRD.
\end{abstract}

Kata Kunci: koeksistensi, koeksistensi, rumah kaum Walaka, bangunan DPRD 


\section{PENDAHULUAN}

Suatu proses penumbuhan dan pengembangan nilai-nilai luhur yang terpancar dari hati nurani dan direfleksikan dalam pemikiran, sikap, dan perilaku disebut jatidiri (Muladi, 2006). Jati diri pada masyarakat tradisional lebih diwujudkan sebagai pencerminan kemampuan kreatif masyarakat dalam mengejewantahkan perilaku budayanya dan bukan sekedar kekhasan produk budaya yang identik sepanjang waktu (Resmiwati, 2010). Modernisasi yang tidak terkontrol pada abad 21 telah meluluhlantahkan siapa jati diri bangsa Indonesia ini sebenarnya. Seluruh wajah wilayah di negeri ini berubah menjadi bentuk kota yang seragam. Dalam bidang arsitektur, terasa sekali adanya upaya menemukan kembali jati diri dalam setiap karya. Gejala tersebut harus tetap dicermati, agar tidak mengutamakan penampilan fisik tetapi mengabaikan makna yang esensial. Hasil usaha aplikasi tersebut juga bevariasi. Budihardjo (1997) dan Ali (2008), mengkhawatirkan aplikasi yang dilakukan hanyalah di luar tanpa mempertimbangan konteksnya.

Dalam pandangan Romantisisme dan Historisisme terdapat kecenderungan untuk lebih mengangkat budaya daripada peradaban. Dalam dikotomi ini, watak suatu masyarakat ditampilkan oleh otentitas budayanya. Jati diri suatu masyarakat ditentukan oleh watak khas ini. Masyarakat lain dapat dibedakan dari watak khas ini (Widyarta, 2007). Jati diri arsitektur Indonesia tumbuh secara alami bila arsitek tidak terpasung pada persepsi visual saja, melainkan juga memasukkan pertimbangan budaya yang khas (Budihardjo, 2005).

Respon internal yang menstimulir eksternal disebut makna (Safanayong, 2006). Makna terletak di dalam diri manusia dan bisa diubah. Acuan dibutuhkan oleh makna (Sobur, 2006). Simbolik (kata sifat) disebut juga sebagai lambang, menjadi lambang, mengetahui lambang. Plato (427-347) dan Plotinos (204-270) mengemukakan bahwa simbol merupakan tempat penyembunyian rohani yang abadi. Menurut Jaspers (1883-1969) simbol disebut sebagai tempat bagi kehadiran Yang-Transenden. Eliade (1907-1986) mengemukakan bahwa simbol diformalisasikan dalam ritual dan mitos (Bakker, 1995).

Koeksistensi adalah proses kerjasama antar dua gaya atau lebih gaya arsitektur yang berbeda dan saling bersinergi (Amal \& Azsahrah, 2018). Keindahan arsitektur ditampilkan dari situasi keunikan alam setempat. Hal ini disebabkan kedua kutub berbeda kodrat dan setiap perbedaan merupakan rahmat llahi. Oleh karena itu, keduanya dapat digabungkan secara bersamaan (Pratikno, 2011). Perbedaan terdapat dalam penghayatan Bali dan Jawa Tengah, antara Srikandi dan Sumbadra, serta dalam banyak aspek, seperti perbedaan antara Bung Karno dan Bung Hatta. Keduanya punya kekuatan, kelemahan dan hikmah masing-masing, keduanya manusiawi, dan hendaknya saling melengkapi dan memperkaya (Mangunwijaya, 2009).

Pembagian kekuasaan yang luas antara Kaomu dan Walaka terdapat dalam sistem pemerintahan kesultanan Buton. Kaum Walaka dan kaum Kaomu berdomisili di pusat kesultanan bukit benteng Keraton Wolio (Zahari, 1977). Simbol ketinggian, istana, dan pemerintahan yang terletak di bukit bermakna kekuasaan. Kaum Kaomu (bangsawan) terbagi menjadi Tanailandu, Tapitapi, dan Kumbewaha (Zahari, 1997). Tiang istana terbagi menjadi tiang tengah, utama, dan pembantu. Ketiga tiang diibaratkan sebagai simbol ketiga keturunan Kaomu seperti Tanailandu, Tapitapi, dan Kumbewaha (Ahmadi, 2009). Kekuasaan di Kesultanan Buton dipegang oleh kaum Kaomu dan kaum Walaka (Schoorl, 2003). Rumah berbentuk Malige pada masa kesultanan Buton hanya boleh dibangun oleh kaum Kaomu dan pejabat kesultanan, sedangkan kaum Walaka dan masyarakat yang tidak mempunyai kedudukan tidak diperkenankan membangun (Kadir, 2000).

Masyarakat Buton Lama terdiri dari kaum Kaomu, kaum Walaka, kaum Maradika, dan kaum Batua. Sistem stratifikasi masyarakat ini tercermin juga dalam huniannya. Filosofi Sara Pataanguna pra Islam dan filosofi Sara Pataanguna pasca Islam merupakan filosofi rumah tradisional Buton kaum Walaka yang mempunyai kedudukan, karena prinsip filosofi Sara Pataanguuna terkandung pada makna dan fungsi dari berbagai simbol rumahnya. Pomaa-maasiaka diartikan sebagai sikap saling menyayangi, sikap saling mengunjungi, dan sikap saling menyapa keluarga. Pomae-maeka diartikan sebagai sikap saling merasa takut, sikap saling hormat, sikap patuh, sikap saling taat terhadap orang yang lebih tua atau pemimpin, dan sikap adil dan teladan terhadap yang lebih muda atau bawahan. Popia-piara diartikan sebagai sikap saling memeliharadan sikap saling menjunjung tinggi kesetaraan. Poangka-angkataka diartikan sebagai sikap saling menghormati, sikap saling menghargai, sikap saling mengutamakan, dan sikap saling memuliakan di antara sesama (Umar, 2017). Penelitian ini ditujukan untuk mengidentifikasi koeksistensi antara rumah kaum Walaka dengan bangunan DPRD Kota Baubau.

\section{METODE PENELITIAN}

Penelitian yang dilakukan di Kota Baubau, Kabupaten Buton, Provinsi Sulawesi Tenggara merupakan penelitian kualitatif dengan pendekatan kausal komparatif terhadap rumah kaum Walaka dan bangunan DPRD Kota Baubau Pengumpulan data dilakukan dengan cara observasi, studi literatur, dan diskusi mendalam terhadap tokoh masyarakat setempat. Filosofi, makna, simbol, dan fungsi digunakan sebagai indikator dalam penelitian ini. Data dibuat dalam bentuk tabulasi dan dianalisis secara deskriptif, sehingga koeksistensi teridentifikasi. 


\section{HASIL DAN PEMBAHASAN}

Sistem sosial dalam masyarakat Buton cenderung bukan kasta, tetapi pembagian tugas kerja. Kaum Walaka ditugaskan sebagai pengawas pemerintahan dan disetarakan dengan tugas DPRD selaku pengawas (legislatif) pemerintahan di Kota Baubau.
Konsep filosofi, makna, simbol, fungsi rumah kaum Walaka dan bangunan DPRD pada aspek arsitektural mengandung prinsip politis yang dimaknai untuk kepentingan orang banyak. Secara garis besar hasil identifikasi koeksistensi antara rumah kaum Walaka dengan bangunan DPRD di Kota Baubau terlihat pada tabel 1 berikut

Tabel 1. Identifikasi koeksistensi arsitektural rumah kaum Walaka dengan Bangunan DPRD di Kota Baubau

\begin{tabular}{|c|c|c|c|c|c|}
\hline \multirow{2}{*}{\multicolumn{2}{|c|}{$\begin{array}{l}\text { Elemen } \\
\text { arsitektural }\end{array}$}} & \multirow{2}{*}{ Konsep } & \multicolumn{2}{|c|}{ Perbedaan } & \multirow{2}{*}{$\begin{array}{l}\text { Koeksis } \\
\text { tensi }\end{array}$} \\
\hline & & & Rumah kaum Walaka & Kantor DPRD & \\
\hline \multirow{20}{*}{$\begin{array}{l}\frac{5}{\pi} \\
\frac{\pi}{0} \\
\frac{0}{0}\end{array}$} & \multirow{4}{*}{$\begin{array}{l}\text { Galampa } \\
\text { (teras) }\end{array}$} & Filosofi & Poangka-angkata & Melayani masyarakat luas & Ada \\
\hline & & Makna & Kekal dan fana & Pengayom masyarakat & Ada \\
\hline & & Simbol & Galampa & entrance & Ada \\
\hline & & Fungsi & $\begin{array}{l}\text { Menerima tamu dan mengintai para putra } \\
\text { Sultan yang akan dijadikan Sultan }\end{array}$ & Menerima tamu dan carport & Ada \\
\hline & \multirow{4}{*}{$\begin{array}{l}\text { Ruang } \\
\text { depan } \\
\text { (bamba) }\end{array}$} & Filosofi & Pomaa-maasiaka & Ruang depan & Ada \\
\hline & & Makna & Profan & Profan & Ada \\
\hline & & Simbol & Ruang depan (bamba) & Ruang sidang & Ada \\
\hline & & Fungsi & Menerima tamu dan bermusyawarah & Ruang sidang & Ada \\
\hline & \multirow{4}{*}{$\begin{array}{l}\text { Kolong } \\
\text { (kapeo) }\end{array}$} & Filosofi & Popia-piara & Struktur bawah & Ada \\
\hline & & Makna & Profan & Profan & Ada \\
\hline & & Simbol & Kolong (kapeo) & Pondasi bangunan & Ada \\
\hline & & Fungsi & $\begin{array}{l}\text { Ruang tamu istirahat dan ruang tidur } \\
\text { pembantu }\end{array}$ & Pondasi bangunan & Tidak ada \\
\hline & \multirow{4}{*}{$\begin{array}{l}\text { Sasambiri } \\
\text { tangke } \\
\text { bala }\end{array}$} & Filosofi & Pomae-maeka & Tangan kiri dan tangan kanan pada manusia & Ada \\
\hline & & Makna & Pejabat kesultanan, pelindung rakyat & Melindungi masyarakat & Ada \\
\hline & & Simbol & Sasambiri tangkebala & Konsol overstek & Ada \\
\hline & & Fungsi & Ruang tidur anak dan keluarga & Overstek / penopang atap & Tidak ada \\
\hline & \multirow{4}{*}{$\begin{array}{l}\text { Bentuk } \\
\text { pabate } \\
\text { kotak di } \\
\text { dapur }\end{array}$} & Filosofi & Pomae-maeka & Tangan kiri pada manusia & Ada \\
\hline & & Makna & Pejabat kesultanan, pelindung rakyat & Melindungi masyarakat & Ada \\
\hline & & Simbol & Bentuk pabate kotak di dapur & Konsol overstek & Ada \\
\hline & & Fungsi & $\begin{array}{l}\text { Menyimpan barang-barang kebutuhan } \\
\text { sehari-hari }\end{array}$ & Overstek dan penopang atap & Tidak ada \\
\hline \multirow{16}{*}{$\begin{array}{l}\text { व } \\
\frac{\pi}{0} \\
\overline{0} \\
0 \\
0\end{array}$} & \multirow{3}{*}{$\begin{array}{l}\text { Tiang } \\
\text { utama } \\
\text { (kabelai) }\end{array}$} & Filosofi & Poangka-angkata & $\begin{array}{l}\text { DPRD bertugas mengawasi jalannya } \\
\text { pemerintahan di Kota Baubau }\end{array}$ & Ada \\
\hline & & Makna & Walaka adalah pengawal Kaomu & Dinamis & Ada \\
\hline & & Simbol & Tiang utama (kabelai). & $\begin{array}{l}\text { Tiang utama di ruang sidang terletak } \\
\text { dideretan pertama }\end{array}$ & Ada \\
\hline & \multirow{5}{*}{$\begin{array}{l}\text { Tada } \\
\text { kambero } \\
\text { (siku } \\
\text { kipas) }\end{array}$} & Fungsi & Letak duduk peghuni dalam menerima tamu & Sistem struktur rangka & Ada \\
\hline & & Filosofi & Pomae-maeka & Memimpin masyarakat & Ada \\
\hline & & Makna & Pejabat kesultanan, pelindung rakyat & Pengayom masyarakat & Ada \\
\hline & & Simbol & Tada kambero (siku kipas) & Penyiku konsol overstek & Ada \\
\hline & & Fungsi & Pengikat bangunan & Penyiku konsol overstek & Ada \\
\hline & \multirow{4}{*}{$\begin{array}{l}\text { Jendela } \\
\text { besar, } \\
\text { luas, dan } \\
\text { berteralis }\end{array}$} & Filosofi & Pomae-maeka & Kokoh dan netral & Tidak ada \\
\hline & & Makna & Penghuni baik fisik maupun wibawanya & Kewibawaan & Ada \\
\hline & & Simbol & Jendela besar, luas, dan teralis & Jendela besar, luas, dan berteralis & Ada \\
\hline & & Fungsi & $\begin{array}{l}\text { Jendela teralis agar anak-anak tidak jatuh ke } \\
\text { bawah. }\end{array}$ & Faktor keamanan bangunan & Ada \\
\hline & \multirow{4}{*}{$\begin{array}{l}\text { Kasolaki } \\
\text { (kaki kuda- } \\
\text { kuda) dan } \\
\text { tutumbu } \\
\text { (ander) }\end{array}$} & Filosofi & Poangka-angkataka & Kokoh dan netral & Ada \\
\hline & & Makna & Tanggung jawab & Kewibawaan & Ada \\
\hline & & Simbol & Kasolaki dan tutumbu & Kaki kuda-kuda dan tiang tutumbu & Ada \\
\hline & & Fungsi & $\begin{array}{l}\text { Tutumbu sebagai balok gantung. Kasolaki } \\
\text { sebagai pembentuk kemiringan atap }\end{array}$ & $\begin{array}{l}\text { Balok ander dan pembentuk kemiringan } \\
\text { atap yang digunakan sebagai kaki kuda- } \\
\text { kuda dan tiang tutumbu termodifikasi }\end{array}$ & Ada \\
\hline \multirow{8}{*}{ 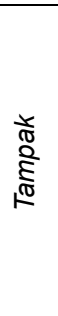 } & \multirow{4}{*}{ Bosubosu } & Filosofi & Pomae-maeka & Memimpin masyarakat & Ada \\
\hline & & Makna & Pejabat kesultanan, pelindung rakyat & Pengayom masyarakat & Ada \\
\hline & & Simbol & Bosubosu & Konsol overstek tanpa ornamen & Ada \\
\hline & & Fungsi & Tempat air minum & Konsol overstek & Tidak ada \\
\hline & \multirow{4}{*}{$\begin{array}{l}\text { Bentuk } \\
\text { atap } \\
\text { rumah } \\
\text { bersusun }\end{array}$} & Filosofi & Pomae-maeka & Melindungi masyarakat & Ada \\
\hline & & Makna & Pemimpin dalam pemerintahan dan agama & Pengayom masyarakat & Ada \\
\hline & & Simbol & Bentuk atap rumah bersusun & Bentuk atap rumah bersusun dimodifikasi & Ada \\
\hline & & Fungsi & $\begin{array}{l}\text { Ruang sholat perempuan, ruang tidur anak } \\
\text { gadis, dan ruang penyimpanan barang }\end{array}$ & Konstrusi atap & Tidak ada \\
\hline
\end{tabular}

Sumber: Hasil analisis, 2018 


\subsection{Koeksistensi}

\subsubsection{Denah}

Poangka-angkataka difilosofikan dalam galampa pada rumah kaum Walaka. Poangka-angkataka berkoeksistensi dengan melayani masyarakat yang difilosofikan dalam entrance pada bangunan DPRD. Kekal dan fana dimaknai dalam galampa pada rumah kaum Walaka. Kekal dan fana berkoeksistensi dengan pengayom masyarakat yang dimaknai dalam entrance pada bangunan DPRD. Galampa disimbolkan pada rumah kaum Walaka. Galampa berkoeksistensi dengan entrance yang disimbolkan pada bangunan DPRD. Menerima tamu dan mengintai putra-putra sultan digunakan dalam galampa pada rumah kaum Walaka. Menerima pada tamu pada galampa berkoeksistensi dengan menerima tamu yang digunakan dalam entrance pada bangunan DPRD.

Pomaa-maasiaka difilosofikan dalam bamba pada rumah kaum Walaka. Pomaa-maasiaka berkoeksistensi dengan analogi tubuh manusia (kaki/ruang depan) yang difilosofikan dalam ruang sidang pada bangunan DPRD. Profan dimaknai dalam bamba pada rumah kaum Walaka. Profan berkoeksistensi dengan profan yang dimaknai dalam ruang sidang pada bangunan DPRD. Bamba disimbolkan pada rumah kaum Walaka. Bamba berkoeksistensi dengan ruang sidang yang disimbolkan pada bangunan DPRD. Aktivitas menerima tamu dan bermusyawarah pada ruang sidang DPRD digunakan dalam bamba pada rumah kaum Walaka. Aktivitas menerima tamu dan bermusyawarah berkoeksistensi dengan ruang sidang pada bangunan DPRD (Gambar 1).

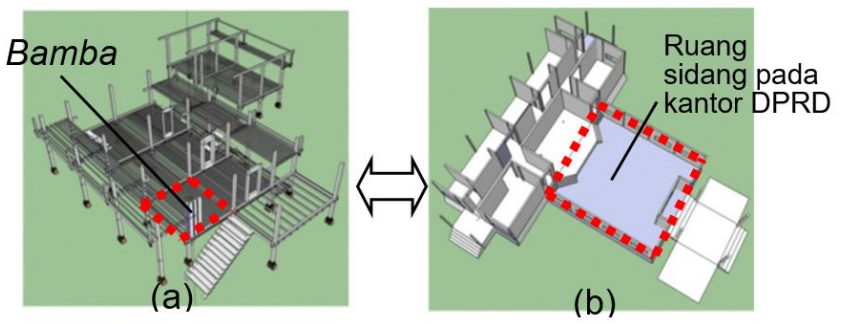

Gambar 1. (a) Bamba (ruang depan) pada rumah Walaka dan (b) Ruang sidang pada Kantor DPRD (Sumber: hasil dokumentasi, 2012)

Popia-piara difilosofikan dalam kapeo pada rumah kaum Walaka. Popia-piara berkoeksistensi dengan analogi tubuh manusia (kaki) yang difilosofikan dalam pondasi bangunan pada bangunan DPRD. Profan dimaknai pada pondasi rumah kaum Walaka. Profan dalam kapeo berkoeksistensi dengan profan dalam pondasi bangunan pada bangunan DPRD. Kapeo disimbolkan pada rumah kaum Walaka. Kapeo berkoeksistensi dengan simbol pondasi bangunan DPRD (Gambar 2).

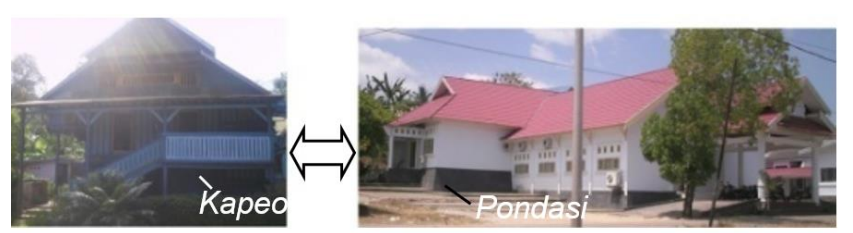

(a)

(b)

Gambar 2. (a) kapeo (kolong) di rumah kaum Walaka dan (b) pondasi bangunan di bangunan DPRD (Sumber: hasil dokumentasi, 2012)

Pomae-maeka difilosofikan dalam sasambiri tangkebala pada rumah kaum Walaka. Pomae-maeka berkoeksistensi dengan analogi tubuh manusia (tangan kiri dan tangan kanan) yang difilosofikan dalam konsol overstek pada bangunan DPRD. Penghuni merupakan pejabat kesultanan, pelindung, dan penggembala rakyat dimaknai dalam sasambiri tangkebala pada rumah kaum Walaka. Penghuni merupakan pejabat kesultanan, pelindung, dan penggembala rakyat berkoeksistensi dengan pelindung masyarakat yang dimaknai dalam konsol overstek pada bangunan DPRD. Sasambiri tangkebala disimbolkan pada rumah kaum Walaka. Sasambiri tangkebala berkoeksistensi dengan konsol overstek yang disimbolkan pada bangunan DPRD.

Pomae-maeka difilosofikan dalam bentuk pabate kotak pada rumah kaum Walaka. Pomae-maeka berkoeksistensi dengan analogi tubuh manusia (tangan kiri) yang difilosofikan dalam konsol overstek pada bangunan DPRD. Penghuni merupakan pejabat kesultanan, pelindung, dan penggembala rakyat dimaknai dalam bentuk pabate kotak pada rumah kaum Walaka. Penghuni merupakan pejabat kesultanan berkoeksistensi dengan pelindung masyarakat dimaknai dalam konsol overstek pada bangunan DPRD. Bentuk pabate kotak disimbolkan dalam rumah kaum Walaka. Bentuk pabate kotak berkoeksistensi dengan konsol overstek yang disimbolkan pada bangunan DPRD (Gambar 3).

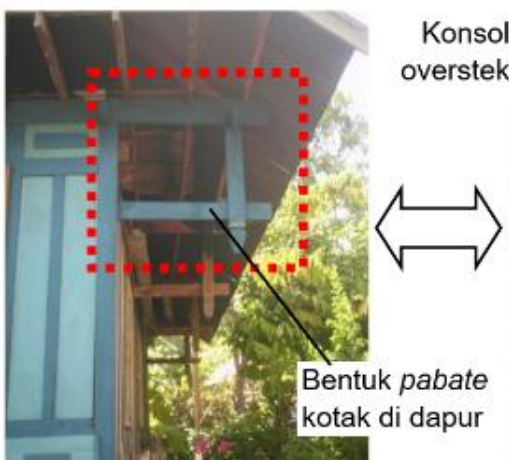

(a)

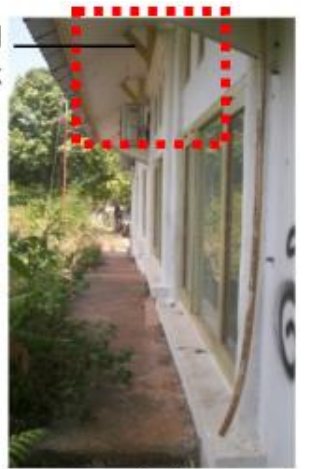

(b)
Gambar 3. (a) bentuk pabate kotak di rumah Walaka dan (b) konsol overstek pada bangunan DPRD (Sumber: hasil dokumentasi, 2012) 


\subsubsection{Potongan}

Poangka-angkataka difilosofikan dalam tiang utama (kabelai) pada rumah kaum Walaka. Poangkaangkataka berkoeksistensi dengan DPRD bertugas mengawasi jalannya pemerintahan otonomi daerah di Kota Baubau yang difilosofikan dalam tiang utama dalam ruang sidang bagian deret pertama pada bangunan DPRD. Kaum Walaka sebagai pengawal kaum Kaomu dimaknai dalam tiang utama (kabelai) pada rumah kaum Walaka. Kaum Walaka sebagai pengawal kaum Kaomu berkoeksitensi dengan dinamis yang dimaknai dalam tiang utama di ruang sidang bagian deretan pertama pada bangunan DPRD. Tiang utama (kabelai) disimbolkan pada rumah kaum Walaka. Tiang utama (kabelai) berkoeksistensi dengan tiang utama di ruang sidang bagian deretan pertama yang disimbolkan pada bangunan DPRD. Kabelai digunakan sebagai letak duduk penghuni dalam menerima tamu. Kabelai berkoeksistensi dengan struktur rangka bangunan yang digunakan pada bangunan DPRD.

Pomae-maeka difilosofikan dalam tada kambero pada rumah kaum Walaka. Pomae-maeka berkoeksistensi dengan memimpin masyarakat difilosofikan dalam penyiku konsol overstek pada bangunan DPRD. Penghuni merupakan pejabat kesultanan, pelindung, dan penggembala rakyat dimaknai dalam tada kambero pada rumah kaum Walaka. Penghuni merupakan pejabat kesultanan, pelindung, dan penggembala rakyat berkoeksistensi dengan makna pengayom masyarakat yang dimaknai dalam penyiku konsol overstek pada bangunan DPRD. Tada kambero disimbolkan pada rumah kaum Walaka. Tada kambero berkoeksistensi dengan penyiku konsol overstek yang disimbolkan pada bangunan DPRD. Tada kambero digunakan sebagai pengikat bangunan. Tada kambero berkoeksistensi dengan penyiku konsol overstek yang digunakan sebagai penyiku konsol overstek.

Penghuni memiliki fisik dan wibawa yang baik dimaknai dalam jendela berukuran besar, luas, dan berteralis pada rumah kaum Walaka. Penghuni memiliki fisik dan wibawa yang baik berkoeksistensi dengan kewibawaan yang dimaknai dalam jendela berukuran besar, luas, dan berteralis pada bangunan DPRD. Jendela berukuran besar, luas, dan berteralis disimbolkan dalam rumah kaum Walaka. Jendela berukuran besar, luas, dan berteralis berkoeksistensi dengan jendela berukuran besar, luas, dan berteralis yang disimbolkan juga pada bangunan DPRD. Jendela berukuran besar, luas, dan berteralis digunakan agar anak-anak tidak terjatuh ke bawah pada rumah kaum Walaka. Jendela berukuran besar, luas, dan berteralis berkoeksistensi dengan jendela berukuran besar, luas, dan berteralis yang digunakan sebagai faktor keamanan bangunan pada bangunan DPRD (Gambar 4).

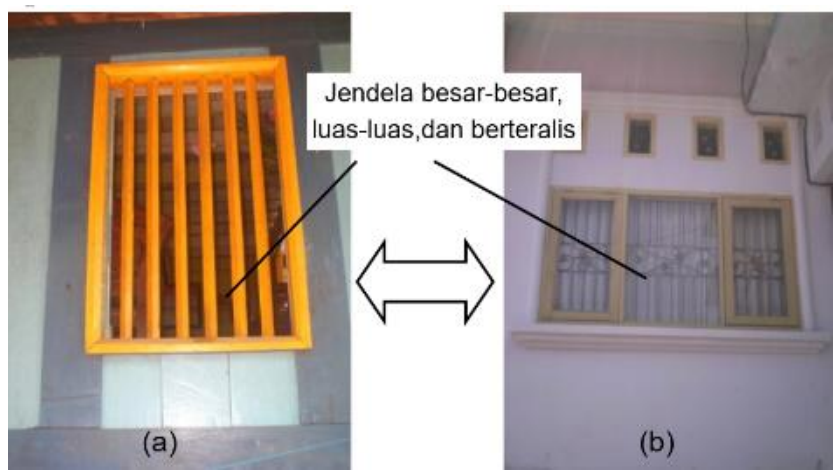

Gambar 4. (a) Jendela berukuran besar, luas, dan berteralis di rumah Walaka dan (b) Jendela besar, luas, dan berteralis pada bangunan DPRD (Sumber: hasil dokumentasi, 2012)

Poangka-angkataka difilosofikan dalam kasolaki (kaki kuda-kuda) dan tiang tutumbu (ander) pada rumah kaum Walaka. Poangka-angkataka berkoeksistensi dengan kokoh dan netral yang difilosofikan dalam kaki kuda-kuda dan tiang tutumbu yang telah dimodifikasi pada bangunan DPRD. Tanggungjawab dimaknai dalam kasolakidan tiang tutumbu pada rumah kaum Walaka. Tanggungjawab berkoeksistensi dengan kewibawaan yang dimaknai dalam kaki kuda-kuda dan tiang tutumbu termodifikasi pada bangunan DPRD. Kasolaki dan tiang tutumbu disimbolkan dalam rumah kaum Walaka. Kasolaki dan tiang tutumbu berkoeksistensi dengan kaki kuda-kuda dan tiang tutumbu termodifikasi yang disimbolkan pada bangunan DPRD. Tiang tutumbu sebagai balok gantung dan kasolaki sebagai pembentuk kemiringan atap digunakan pada rumah kaum Walaka. Tiang tutumbu sebagai balok gantung dan kasolaki sebagai pembentuk kemiringan atap berkoeksistensi dengan balok ander dan pembentuk kemiringan atap yang digunakan sebagai kaki kuda-kuda dan tiang tutumbu termodifikasi pada bangunan DPRD.

\subsubsection{Tampak}

Pomae-maeka difilosofikan dalam bosubosu pada rumah kaum Walaka. Pomae-maeka berkoeksistensi pemimpin masyarakat yang difilosofikan dalam konsol overstek tanpa ornamen pada bangunan DPRD. Penghuni merupakan pejabat kesultanan, pelindung, dan penggembala rakyat dimaknai dalam bosubosu pada rumah kaum Walaka. Penghuni merupakan pejabat kesultanan, pelindung, dan penggembala rakyat berkoeksistensi dengan pengayom masyarakat yang difilosofikan dalam konsol overstek tanpa ornamen pada bangunan DPRD. Bosubosu disimbolkan pada rumah kaum Walaka dan berkoeksistensi dengan konsol overstek tanpa ornamen yang disimbolkan pada bangunan DPRD. 


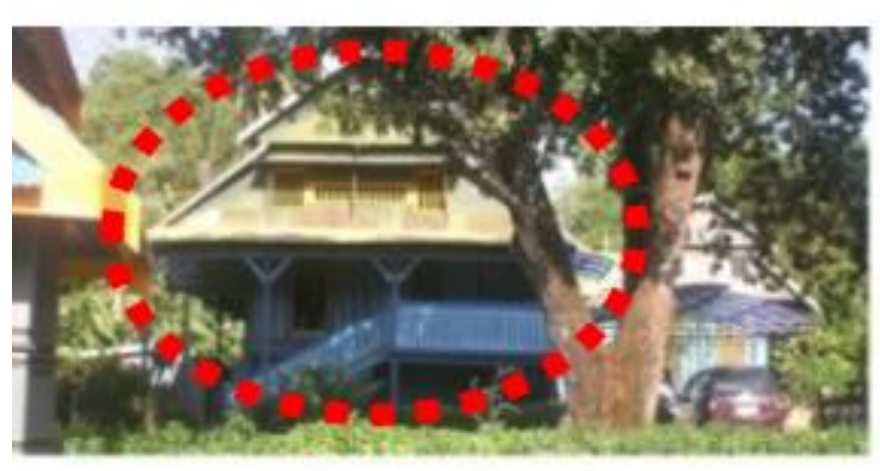

(a)

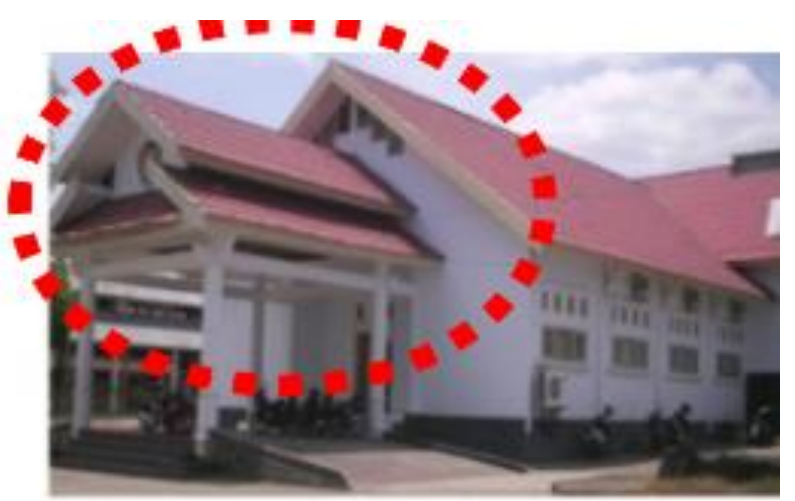

(b)

Gambar 5. (a) Bentuk atap rumah bersusun di rumah kaum Walaka dan (b) Bentuk atap rumah bersusun termodifikasi pada bangunan DPRD (Sumber: hasil dokumentasi, 2012)

Pomae-maeka difilosofikan dalam bentuk atap rumah bersusun pada rumah kaum Walaka. Pomae-maeka berkoeksistensi dengan pelindung masyarakat difilosofikan dalam bentuk atap rumah bersusun termodifikasi pada bangunan DPRD. Pemimpin dalam pemerintahan dan agama dimaknai dalam bentuk atap rumah bersusun pada rumah kaum Walaka. Pemimpin dalam pemerintahan dan agama berkoeksistensi dengan pengayom masyarakat yang dimaknai dalam bentuk atap rumah bersusun termodifikasi pada bangunan DPRD. Bentuk atap rumah bersusun disimbolkan pada rumah kaum Walaka. Atap rumah susun berkoeksistensi dengan bentuk atap rumah bersusun modifikasi disimbolkan pada bangunan DPRD (gambar 5).

\subsection{Tidak Koeksistensi}

\subsubsection{Denah}

Ruang kolong (kapeo) digunakan sebagai ruang tamu untuk istirahat dan ruang tidur pembantu. Koeksistensi tidak terdapat antara ruang kolong (kapeo) dan pondasi yang digunakan pada bangunan DPRD. Ruang sasambiri tangkebala digunakan sebagai ruang tidur anak dan keluarga pada rumah kaum Walaka. Koeksistensi tidak terdapat antara ruang sasambiri tangkebala dan konsol overstek yang digunakan sebagai penopang atap pada bangunan DPRD. Bentuk pabate kotak digunakan sebagai ruang penyimpanan barang kebutuhan sehari-hari pada rumah kaum Walaka. Koeksistensi tidak terdapat antara bentuk pabate kotak dan konsol overstek yang digunakan sebagai overstek serta penopang atap pada bangunan DPRD.

\subsubsection{Potongan}

Pomae-maeka difilosofikan dalam bentuk jendela besar-besar, luas-luas, dan berteralis pada rumah kaum Walaka. Koeksistensi tidak terdapat antara filosofi pomae-maeka dan kokoh serta netral yang difilosofikan pada bangunan DPRD.

\subsubsection{Tampak}

Bosubosu digunakan sebagai tempat air minum penghuni pada rumah kaum Walaka. Koeksistensi tidak terdapat antara bosubosu dan konsol overstek tanpa ornamen yang digunakan sebagai konstruksi atap pada bangunan DPRD. Atap bersusun digunakan sebagai ruang sholat perempuan, ruang tidur anak gadis, dan ruang menyimpan barang pada rumah kaum Walaka. Koeksistensi tidak terdapat antara atap bersusun rumah kaum Walaka dan atap bersusun yang digunakan hanya sebagai konstruksi atap pada bangunan DPRD.

\section{KESIMPULAN}

Penelitian ini menyimpulkan bahwa koeksistensi rumah kaum Walaka dan bangunan DPRD terdapat dalam filosofi, makna, simbol, fungsi denah, tampak, serta potongan yang telah dimodifikasi. Koeksistensi tidak terdapat pada rumah kaum Walaka yang mempunyai kedudukan dan bangunan DPRD. Koeksistensi tidak terdapat antara kolong rumah kaum Walaka dan pondasi bangunan DPRD; antara sasambiri tangkebala (rumah kaum Walaka) dan konsol overstek bangunan DPRD; antara pabate berbentuk kotak (rumah kaum Walaka) dan konsol overstek pada bangunan DPRD.

Koeksistensi juga tidak ditemui dalam filosofi dan makna antara bentuk jendela berukuran besar, luas, dan berteralis pada rumah kaum Walaka) dengan filosofi dan makna pada bangunan DPRD; antara bosubosu (rumah kaum Walaka) dan konsol overstek tanpa ornamen pada Bangunan DPRD, serta antara atap rumah bersusun pada rumah kaum Walaka) dengan atap rumah bersusun pada bangunan DPRD. Penelitian ini dapat dilanjutkan untuk meneliti metode adaptasi rumah tradisional Buton kaum Walaka terhadap kantor pemerintahan di Kota Baubau. 


\section{REFERENSI}

Ahmadi, LOA. (2009). Makna Simbolis pada Istana Malige.

Ali, M. (2008). Arsitektur Tradisional Bugis: Filosofi ke Aplikasi (pp. 1-14). Seminar Nasional Jelajah Arsitektur Tradisional Nusantara dalam Menemukenali Teknologi Berbasis Kearifan Lokal.

Amal, C. A., \& Azsahrah, A. F. (2018). Koeksistensi Antara Arsitektur Bugis Makassar dengan Arsitektur Moderen Pada Bangunan Kantor Pemerintahan di Kota Makassar. LINEARS : Jurnal Teknik Arsitektur, 1(1), 20-27. Retrieved from http://journal.unismuh.ac.id/index.php/linears/articl e/view/1318

Bakker, A. (1995). Kosmologi dan ekologi: filsafat tentang kosmos sebagai rumahtangga manusia. Kanisius.

Budihardjo, E. (1991). Jati diri Arsitektur Indonesia. Alumni.

Budihardjo, E. (1997). Arsitektur sebagai warisan budaya. Djambatan.

Kadir, I. (2000). Perubahan dan Kesinambungan pada perkembangan Rumah Tradisional Buton di Kawasan Benteng Keraton Buton Sulawesi Tenggara (Thesis). Universitas Gadjah Mada, Yogyakarta.

Mangunwijaya, Y. B. (2009). Wastu citra: pengantar ke ilmu budaya bentuk arsitektur, sendi-sendi filsafatnya, beserta contoh-contoh praktis. Jakarta: PT Gramedia Pustaka Utama.
Muladi. (2006). Revitalisasi Jati Diri Bangsa. Presented at the Diskusi Panel Revitalisasi Jati Diri Bangsa oleh Biro Organisasi dan Humas, Deputi Mensesneg Bidang Sumber Daya Manusia bersama Biro Kewilayahan dan Wawasan, Deputi Seswapres Bidang Politik, Jakarta.

Pratikno, P. (2011). Etika \& Estetika Cara-cara Berarsitektur dengan Bijak. Yogyakarta: Penerbit Andi.

Resmiwaty. (2010). Arsitektur yang Beridentitas dan Berjatidiri. Antropologi Arsitektur-3.

Safanayong, Y. (2006). Desain Komunikasi Visual Terpadu. Arte Intermedia.

Schoorl, P. (2008). Kekuasaan, Ideologi, dan Perubahan di Kesultanan Buton. Menyibak Kabut Di Keraton Buton: Bau-Bau: Past, Present, and Future, Respect, Pekmot Bau-Bau, Bau-Bau, Buton, 43-72.

Sobur, A. (2003). Semiotika komunikasi. Remaja Rosdakarya.

Umar, M. Z. (2017). Filosofi Sarapataanguna Pra dan Pasca Islam Sebagai Filosofi Rumah Tradisional Buton Kaum Walaka. EMARA: Indonesian Journal of Architecture, 3(2), 61-67. doi:10.29080/emara.v3i2.151

Widyarta, M. N. (2007). Mencari arsitektur sebuah bangsa: sebuah kisah Indonesia. Surabaya: Wastu Lanas Grafika.

Zahari, A. M. (1977). Sejarah dan Adat Fiy Darul Butuni (Buton) (I). Jakarta: Proyek Pengembangan Media Kebudayaan. 